\title{
A TISSUE-IMPLANT REACTION ASSOCIATED WITH SUBCUTAN IMPLANTATION OF ALPHA-TRICALCIUM PHOSPHATE, DENTAL CERAMIC AND HYDROXYAPATITE BIOCERAMICS IN RATS
}

\author{
STOJANOVIĆ $D^{\star}$, JANAČKOVIĆ $\bigoplus^{\star}$, MARKOVIĆ DANICA**, TASIĆ G***, ALEKSANDRIĆ $B^{\star * * *}$ \\ and KOJIĆ ZVEZDANA***** \\ *Department of Inorganic Chemical Technology, Faculty of Technology and Metalurgy \\ ${ }^{*}$ Department of Histology, Faculty of Veterinary Medicine, Belgrade \\ $* * *$ Institute of Neurosurgery, Clinical Center of Serbia, Belgrade \\ $* * *$ Institute of Forensic Medicine, School of Medicine, Belgrade \\ $\star * * * \star$ Institute of Medical Physiology, School of Medicine, Belgrade
}

(Received 13. December 2007)

Calcium phosphate ceramics are among the more commonly used and biocompatible ceramics. Recently, we have synthesized a new calcium phosphate ceramic, alpha tricalcium phosphate (aTCP). The aim of this study was to assess the biocompatibility of this original, in our laboratory modified, newly synthesized aTCP ceramic, by carefully evaluating the inflammatory reaction of soft tissue in response to its subcutaneous implantation, and by comparing this result with the results of already widely used virtually non-toxic, non-immunogenic, and almost chemically inert dental (DC) and hydroxy apatite (HAP) ceramics. Implants (diameter $5 \times 2 \mathrm{~mm}$ ) of aTCP, DC and HAP were implanted into 12 adult male rats subcutaneously. At 2 weeks and 12 weeks post-implantation, the animals were euthanized and the tissueimplant reactions were analyzed histologically. Evaluation of routine stained sections (5 $\mu \mathrm{m}$, hematoxylin \& eosin) of the cutis and subcutis surrounding the aTCP, DC and HAP ceramics revealed the following: 1) all the ceramic devices had fibrous connective tissue capsules; 2) there were significant differences in the tissue - implant reactions based on the estimated time, while there were no differences in the tissue-implant reaction based on the type of ceramic material; 3) two weeks after implantation hyperemia and cellular proliferation were the most expressive results, while twelve weeks after implantation extensive angiogenesis and collagen fibers production were the prominent findings for all types of implanted calcium phosphate ceramics.

Key words: biocompatibility, biomaterials, calcium phosphate ceramics, inflammation 
Acta Veterinaria (Beograd), Vol. 58. No. 4, 381-393, 2008.

Stojanović $\mathrm{D}$ et al.: A tissue-implant reaction associated with subcutan implantation of alpha-tricalcium phosphate, dental ceramic and hydroxyapatite bioceramics in rats

\section{INTRODUCTION}

Calcium phosphate ceramics, such as tricalcium phosphate (TCP) and hydroxyapatite (HAP), are classified as the most biocompatible materials used in medicine today (Williams, 1981; Williams, 1987; LeGeros and LeGeros, 1996). They are widely used as bone substitutes in orthopaedic, reconstructive and maxillofacial surgery because they have good biocompatibility and extensive bone conductivity (Williams, 1981; Cook and Dalton, 1992; Yamada et al., 2007). However, some problems with these ceramics have been reported (Lu et al., 2004; Fellah et al., 2007). A major problem is that devices implanted within the living tissue must interact with the physiological functions of the host, with no development of foreign body reactions around the implanted material (Coleman et al., 1974; Williams, 1981; Tang et al., 1996; Barile, 2008).

Recently, we have developed a new calcium phosphate cement, an alpha tricalcium phosphate (aTCP). The cement obtained by the modified hydrothermal method, beside aTCP, contains a small quantity of calcium-hydroxyapatite as the residual phase, which could act as a centre for nucleation of newly formed hydroxyapatite (HAP). As a consequence, faster transformation into the HAP phase is observed during the setting of cement paste in simulated body fluid. Further, the HAP obtained by the hydrolysis of this cement has a more compact and denser microstructure with a finer nanostructure and crystal size of newly formed calcium deficient hydroxyapatite (CDHAP) below $100 \mathrm{~nm}$, and compressive strength up to $80 \mathrm{MPa}$ after 3 days of immersion in simulated body fluid (Jokić et al., 2007). The aim of this study was to assess the biocompatibility of this newly synthesized aTCP cement, by carefully evaluating the inflammatory reaction of soft tissue in response to its subcutaneous aTCP implantation, and by comparing this result with the results of already widely used virtually non-toxic, non-immunogenic, and almost chemically inert dental ceramic (DC) and hydroxyapatite (HAP) ceramic.

\section{MATERIALS AND METHODS}

\section{Fabrication of Implants}

I HAP ceramic fabrication:

Synthesis of calcium deficient hydroxyapatite (CDHAP):

Various amounts of $\mathrm{Ca}\left(\mathrm{NO}_{3}\right)_{2} \cdot 4 \mathrm{H}_{2} \mathrm{O}, \mathrm{Na}_{2} \mathrm{H}_{2} \mathrm{EDTA} \cdot 2 \mathrm{H}_{2} \mathrm{O}, \mathrm{NaH}_{2} \mathrm{PO}_{4}$ and urea were dissolved in $2000 \mathrm{~mL}$ of distilled water (see Table 1). All reagents were Merck p.a. grade. The solution was heated at $160^{\circ} \mathrm{C}$ during $2 \mathrm{~h}$ in a sealed tube. The particles were further washed with distilled water and dried at $105^{\circ} \mathrm{C}$ for $2 \mathrm{~h}$ and molded in a disc shape (dimension $5 \times 2 \mathrm{~mm}$ ) on an uniaxial press. Applied pressure was $30 \mathrm{MPa}$. After that prepared disc samples were sterilized in a X-ray chamber during 3 days. 
Acta Veterinaria (Beograd), Vol. 58. No. 4, 381-393, 2008.

Stojanović D et al.: A tissue-implant reaction associated with subcutan implantation of alpha-tricalcium phosphate, dental ceramic and hydroxyapatite bioceramics in rats

Table 1. Fabrication of Implants - HAP and aTCP ceramic fabrication: The precursor contents (in $2000 \mathrm{ml}$ distilled water) for CDHAP synthesis

\begin{tabular}{|c|c|c|c|c|}
\hline & $\begin{array}{c}\mathrm{Ca}\left(\mathrm{NO}_{3}\right)_{2} \cdot 4 \mathrm{H}_{2} \mathrm{O} \\
(\mathrm{g})\end{array}$ & $\begin{array}{c}\mathrm{Na}_{2} \mathrm{H}_{2} \mathrm{EDTA} \cdot 2 \mathrm{H}_{2} \mathrm{O} \\
(\mathrm{g})\end{array}$ & $\begin{array}{c}\mathrm{NaH}_{2} \mathrm{PO}_{4} \cdot 2 \mathrm{H}_{2} \mathrm{O} \\
(\mathrm{g})\end{array}$ & $\begin{array}{c}\mathrm{CO}\left(\mathrm{NH}_{2}\right)_{2} \\
(\mathrm{~g})\end{array}$ \\
\hline \hline $\mathrm{HAP} 1$ & 27.46 & 14.80 & 12.00 & 12.00 \\
\hline
\end{tabular}

HAP - hydroxyapatite, aTCP-aplha tricalcium phosphate, CDHAP - calcium defitient hydroxyapatite

II Preparation of alpha tricalcium-phosphate $\left(\alpha-\mathrm{Ca}_{3}\left(\mathrm{PO}_{4}\right)_{2}\right)$ ceramic:

The $\alpha-\mathrm{Ca}_{3}\left(\mathrm{PO}_{4}\right)_{2}$ cement was obtained by heating dried HAP1 powder at a heating rate of $10^{\circ} \mathrm{C} / \mathrm{min}$ and calcination at $1500^{\circ} \mathrm{C}$ during 2 hours. The heated sample was milled in a ball mill (Fritsch, Germany) with zirconium balls, during 30 minutes. The so obtained cement powder $\mathrm{C} 1$ was further mixed with phosphate solution (2.5 wt.\% solution of $\mathrm{Na}_{2} \mathrm{HPO}_{4}$ ) at a liquid to powder ratio of $0.32 \mathrm{~mL} / \mathrm{g}$ in order to obtain the cement paste CP1. This paste was molded in a discoid shape $(5 \times 2 \mathrm{~mm})$ on an uniaxial press. The pressure applied was $30 \mathrm{MPa}$. Thereof, prepared discs samples were sterilized in a X-ray chamber during 3 days.

\section{Dental ceramic fabrication}

Dental ceramic was obtained by commercially made bioinert dental ceramics VITA VMK 95. The samples were prepared by mixing the ceramic powder with VITA Modelling Fluid and shaped as a disk 5x2 mm in diameter. The samples were heated at $600^{\circ} \mathrm{C}$ for 6 minutes in air, and after that heated up to $930^{\circ} \mathrm{C}$ with a heating rate of $55^{\circ} \mathrm{C} / \mathrm{min}$ in vacuum. The samples were held at this temperature one more minute. The cooled samples were after that glazed with Vita Akzent Powder mixed with Vita Akzent Fluid, and heated at $600^{\circ} \mathrm{C}$ for 4 minutes. Further the dental ceramic disks were heated at a heating rate of $110^{\circ} \mathrm{C} / \mathrm{min}$ up to $930^{\circ} \mathrm{C}$ in air. At this temperature the samples were held for one more minute. After that prepared discs samples were sterilized in a X-ray chamber during 3 days.

\section{Animals and Housing}

This study was conducted according to $\mathrm{NIH}$ guidelines and with the approval of the University of Belgrade School of Medicine's Animal Care Committee on the use and care of animals. Twelve Wistar male albino rats weighing $230 \pm 30 \mathrm{~g}$, bred at the Institute of Physiology, were used. These rats were randomly divided into three groups: two experimental groups and one control group. Animals in Group I were designated for the implantation of the $\alpha \mathrm{TCP}$ ceramic on the left side and dental ceramic on the right side, into the paravertebral region (experimental group 1, $n=4$.) Animals in Group II were marked for HAP implantation on the left side and dental ceramic on the right side, into the paravertebral region (experimental group 2, $n=4$ ). Animals designated in Group III were not implanted, serving as the intact control for comparative purposes (control group, $n=4$ ). All animals in this investigation were kept on a 
Acta Veterinaria (Beograd), Vol. 58. No. 4, 381-393, 2008.

Stojanović $\mathrm{D}$ et al.: A tissue-implant reaction associated with subcutan implantation of alpha-tricalcium phosphate, dental ceramic and hydroxyapatite bioceramics in rats

12-hour day/night cycle and were fed ad libitum and had free access to water. Animals were housed at the Institute of Physiology's animal care facility, School of Medicine and monitored on a daily basis by veterinarians and staff on site.

\section{Implantation}

The aseptic surgical technique was used during the surgical procedure (Fig. 1). Rats were anesthetized with a diethyl ether, as prescribed by the Animal Care Committee. After the anesthesia had taken effect, their dorso-lumbal region was shaved. The incision site was then washed with ethanol and scrubbed with providone iodine. An incision was made into the skin and into the paravertebral (dorsal-back) muscle in the lower dorso-lumbal area, 1.0 to $1.5 \mathrm{~cm}$ from the midline parallel to the vertebral column. Sterilized implants were inserted subcutaneously (s.c.) through the $1.5 \mathrm{~cm}$ incision (Fig. 1A). Each animal from the experimental group was implanted bilaterally: on the right side dental ceramic, on the left side either alpha tricalcium phosphate (Group I) or hydroxyappatite (Group II) (Fig. 1B). The dorsal muscle was sutured with prolene blau monofil, non-resorptive Polipropylen, 2/0, EH 7697. The skin was closed with two sutures (Fig. 1C), and in order to reduce the chance of post-operative infection the skin was scrubbed with providone iodine.
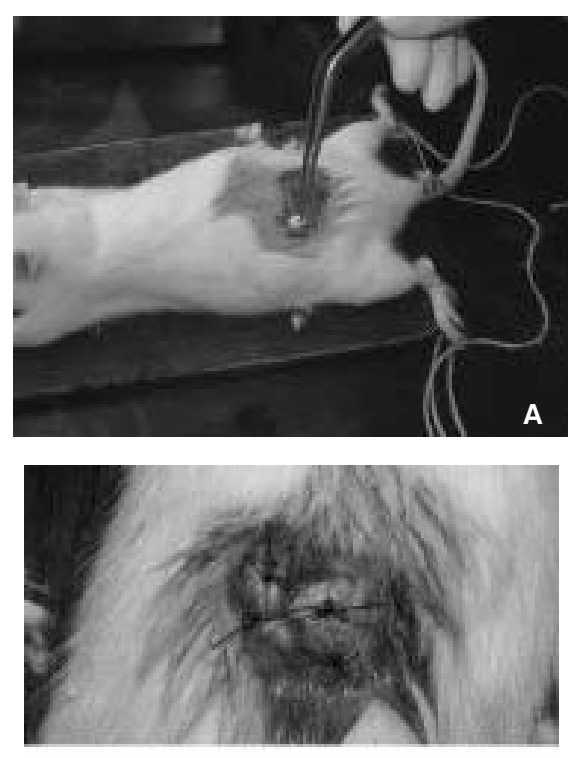

C
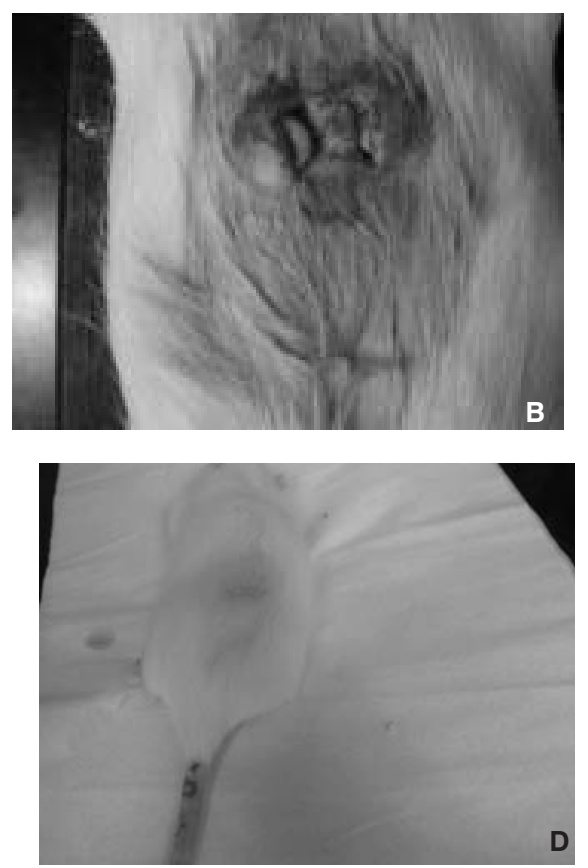

Figure 1. Animal surgery - Implantation procedure. A. Skin and back muscle incision. B. Bilateral paravertebral implantation. C. Suturae. D. Skin, 2 weeks after surgery, implantation (anesthetized rat) 
Acta Veterinaria (Beograd), Vol. 58. No. 4, 381-393, 2008.

Stojanović $\mathrm{D}$ et al.: A tissue-implant reaction associated with subcutan implantation

of alpha-tricalcium phosphate, dental ceramic and hydroxyapatite bioceramics in rats

\section{Tissue Processing}

All animals were euthanized using an overdose of halothane. There were two tissue-implant reaction evaluation periods: at the end of week 2 and 12 weeks after implantation. Half of the total number of animals of each group was sacrificed for each evaluation period. After sacrifice, the implants, with their surrounding tissue, were excised in blocks and fixed in 10\% neutral buffered formalin. The implants were carefully dissected, removed from the fixed tissue, and used for SEM analysis (data are not shown). After routine histological processing, tissue samples were embedded in parafine blocks, cut on a microtone at $5 \mu \mathrm{m}$ and stained with hematoxylin and eosin. A total of 2-3 slides from each implantation site per each animal was prepared. The surrounding tissue reactions to the implant were histologically examined.

\section{Evaluation of Sections}

Histological sections prepared from the tissue directly surrounding the implants were evaluated with the aid of a light microscope. The epidermis, cutis and subcutis were analyzed, as well as the cutaneous muscle with adjoining connective tissue. Ten high power fields were viewed at random per each slide.

\section{Data Analysis and Interpretation}

The tissue was examined and evaluated for the presence of necrosis and inflammation as its reaction to implanted calcium phosphate ceramics (Williams, 1986).

\section{RESULTS}

\subsection{Surgery}

Surgical procedures were performed without complications, and all samples were introduced into the subcutis without being damaged. All rats recovered well and showed no signs of illness within the following 2 and 12 weeks.

\subsection{Macroscopical evaluation}

No significant differences of macroscopical appearance and inflammatory reaction could be found between the examined groups. A fibrous capsule surrounding the implants was visible by light macroscope during tissue processing (excision of soft tissue and implants, aTCP, HAP, DC), at 2 and at 12 weeks after implantation.

\subsection{Histological evaluation}

The results from this investigation demonstrated that there are significant differences in the tissue -implant reactions based on the time of estimation (Figs. 2-7). Two weeks after implantation hyperemia and cellular infiltration were the dominant findings (Figs. 2-4), while twelve weeks after implantation an extensive angiogenesis and collagen synthesis were evident (Figs. 5-7). 
Results from this investigation also demonstrated that, based on the type of ceramic material, there were no significant differences in the tissue-implant reaction. Tissue-implant reactions for each examined period ( 2 and 12 weeks) demonstrated slight variations between the used calcium phosphate ceramics (aTCP, HAP and DC) (Figs. 2-7).

Control. In the control group the structures of the cutis and subcutis corresponding to the animal species were identified. They can be described as uniform epidermis (str. basale, str. spinosum, str. granulosum, str. corneum, str. disjunctum); dermis with visible stratum papillare and stratum reticulare. Subcutis

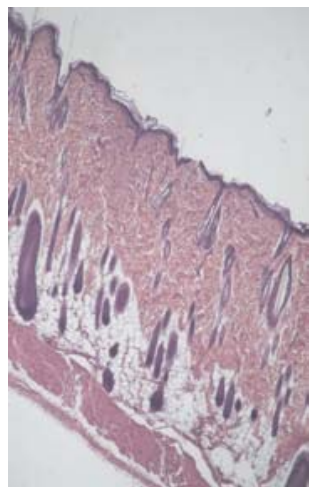
was well developed with noticeable fat tissue. Hair filaments with appropriate sebaceous glands were present. At the level of fibers only collagenous fibers were evident. The cutaneous muscle had layered structures, with two thin longitudinal layers outwards and wider, central one, having perpendicular fibers with notable bands characteristic for muscles of the skeletal type. The adjoining connective tissue was typical loose connective tissue (Fig. 2).

Figure 2. Representative photomicrograph of the of cutis, subcutis and cutaneous muscle of control animal. (H\&E, 4 x)

2 weeks after implantation. Comparing to the control animals, histological analyses revealed the following: epidermis was thin and the stratum papilare of the dermis flat and shallow (Fig. $3 \mathrm{~A}, \mathrm{~B}, \mathrm{C}$ ). Hight cellularity with numerous distinct cell populations was observed (Fig. 4 A, B, C). There was no variation in the
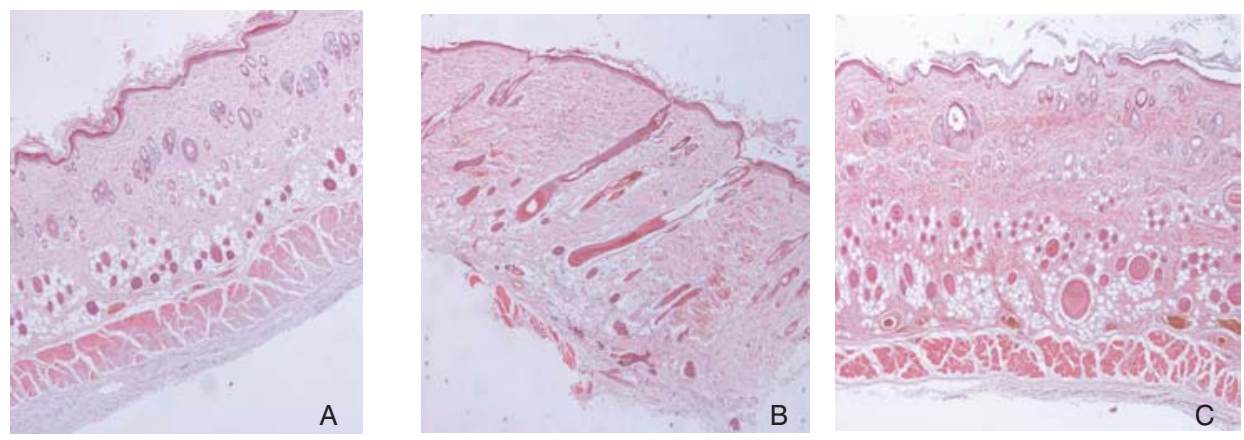

Figure 3. Representative photomicrographs of cutis, subcutis and cutaneous muscle surrounding the implanted bioceramics: $\operatorname{HAP}(A)$, aTCP $(B)$ and $D C(C)$ at 2 weeks post-implantation. Note the hyperaemia with elongated arterial blood vessels in dense fibrous tissue close to cutaneous muscle $(A, B, C)(H \& E, 4$ x) 
cellular components of the tissue surrounding the aTCP and DC bioceramic devices implanted subcutaneously at 2 weeks post-implantation (H\&E, $10 \mathrm{x}$ ). This low power magnification of the tissue surrounding the aTCP and DC bioceramic device (10X) demonstrated thickness and cellularity (B, C). At high power magnification, numerous distinct cell populations, including macrophages, neutrophils, and fibroblasts, were observed $(40 \mathrm{X})$. These figures also demonstrate abundant neutrophils throughout the entire thickness of the fibrous tissue and nests of macrophages were noted in numerous sections of the tissue surrounding the calcium phosphate ceramic when implanted subcutaneously.

Hyperemia of the large blood vessels was noticed (Fig. 3 A, B, C), fat tissue was significantly reduced (Fig. 3B), muscle fibres were edematous (Fig. 3A, Fig. $4 A)$, fasciculus was separated and slighlty unorganized with some discontinuity (Fig. 3C, Fig. 4A).
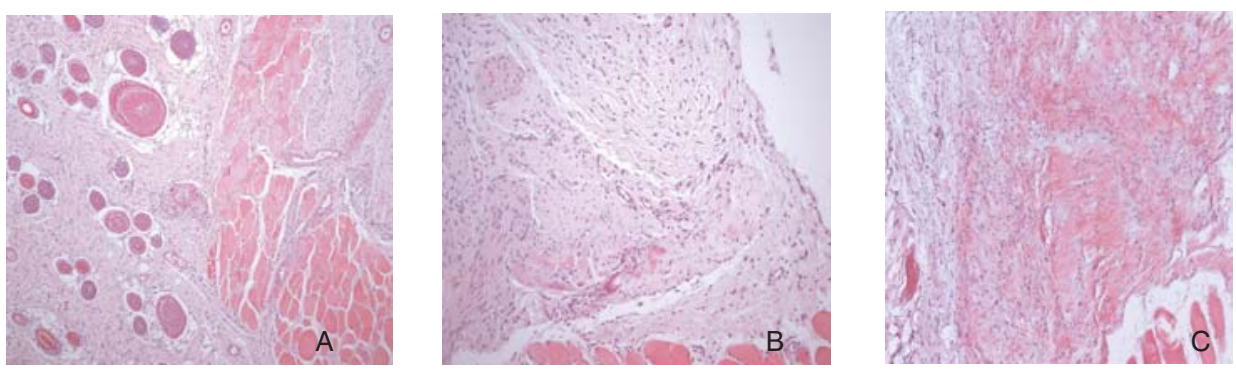

Figure 4. Representative photomicrographs of cutis and cutaneous muscle, surrounding aTCP (A, B) and DC (C) ceramics implanted subcutaneously at 2 weeks postimplantation. In dense connective tissue signs of cellular proliferation and edematous cutaneous muscle were remarkable $(A, B, C)$. Note there is no variation in cellular components in tissue-implant reaction for aTCP and DC (H\&E, $10 \mathrm{x})$

12 weeks after implantation. These photomicrographs vary markedly from those seen at 2 weeks after implantation of the ceramic device with respect to cellularity and vascularity (Figs. 5, 6, 7). Cellularity and hyperemia of large blood vessels were less prominent while the vascularity (angiogenesis, through newly formed capillaries) in the fibro-adipose portion of the tissue was more apparent. Also, the staining reaction of eosin on the fibrous tissue matrix was stronger.

The epidermis was moderately thin, compact (Fig. 5 A, B, C). The connective dermal tissue was edematous, with increased presence of dilaminated fibers (Fig. 5 A, B, C, Fig. 6A). Voluminous extracellular space with fibroblasts-fibrocites (Fig. 7C) was apparent. Some lymphocytes and macrophages were observed, as well (Fig. 6 C, Fig. 7A). 


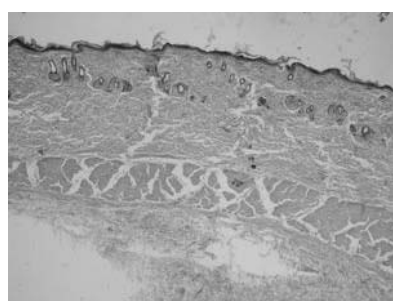

A
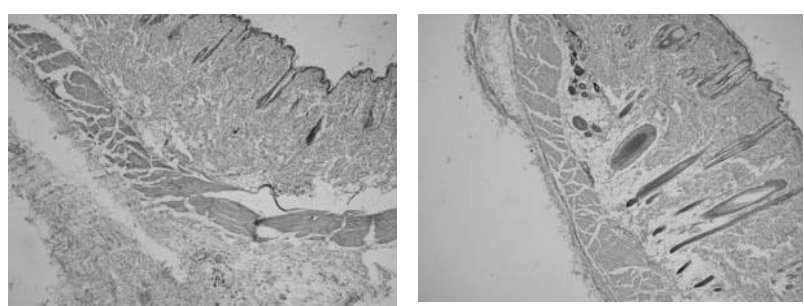

B

Figure 5. Representative photomicrographs demonstrating the vascularity observed in fibrous tissue surrounding HAP (A), DC (B) and aTCP (C) ceramic devices extracted from the subcutaneous tissue 12 weeks after implantation. Corresponding to the control samples the following can be noticed: thinner epithelium, irregular hair follicles uneven-reduced with well formed sebaceous glands, but fewer in all three treated groups (A, B, C); the dermal connective tissue and subcutis, in total, edematic and thick, with notable reduction of fat tissue; the cutaneous muscle thinner, partially with broken fibers; the adjoining loose connective tissue with plenty of newly formed small blood vessels, capillaries (angiogenesis) (H\&E, 4x)

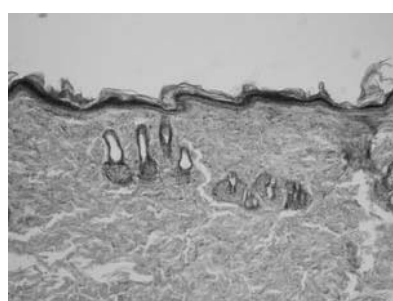

A

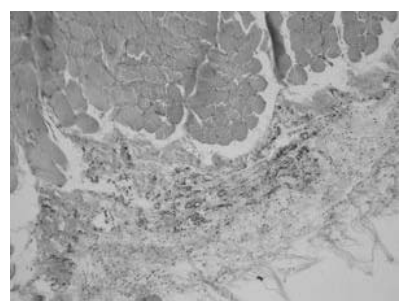

B

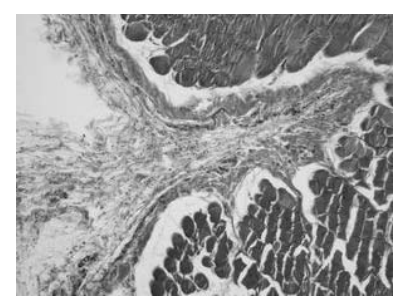

C

Figure 6. Representative photomicrographs of tissue-implant reaction, 12 weeks after implantation of HAP (A), DC (B) and TCP (C). Following can be noticed: delaminated collagenous fibers in all directions of dermis $(A)$; characteristic signs of proliferation in loose connective tissue under the muscle fibers, with numerous newly formed blood capillary network close to muscle (B); perimisum area is wide and edematic, and in adjacent connective tissue line of cellular infiltrates makes a band following the muscle fibers $(\mathrm{C})$. (H\&E, $10 \mathrm{x})$

A layer of fibro-adipose tissue containing small blood vessels and capillaries was noticed. Angiogenesis was well developed in the connective tissue of all analized samples (Fig. 7 A, B, C). A thin layer of fat tissue was locally deposited in the deeper subcutis in animals treated with aTCP (Fig. $5 \mathrm{C}$ ). There was no diference in cutaneous muscle among three calcium phosphate ceramic treated groups: in some cases there were sporadic and slightly edematous fibers (Fig. 6 C, Fig. 7A). 
Acta Veterinaria (Beograd), Vol. 58. No. 4, 381-393, 2008.

Stojanović $\mathrm{D}$ et al.: A tissue-implant reaction associated with subcutan implantation

of alpha-tricalcium phosphate, dental ceramic and hydroxyapatite bioceramics in rats

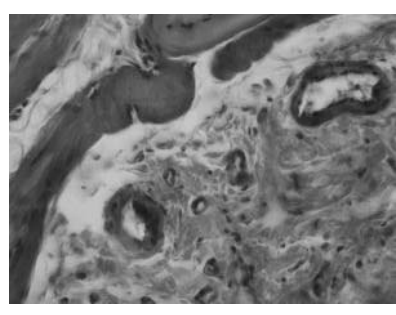

A

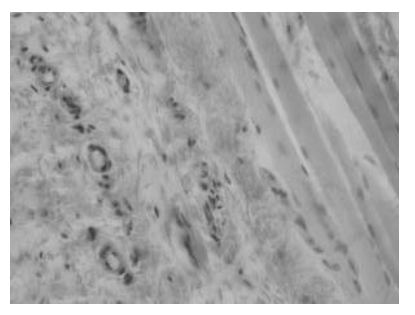

$\mathrm{B}$

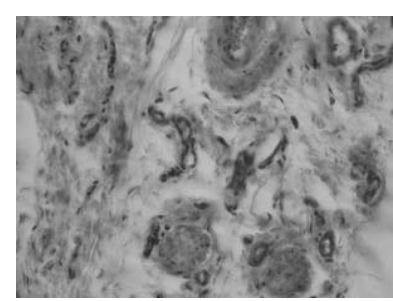

C

Figure 7. Representative photomicrographs of tissue-implant reaction, 12 weeks after implantation of HAP (A), DC (B) and TCP (C). The following can be noticed: the connective tissue surrounding the cutaneous muscle fibers shows the signs of edema and increased content of collagene fibers, "fibroblast-like spindle-shaped cells", mononucleus cell units infiltrate close to blood vessels with local indications of hyperaemia and angiogenesis $(A, B, C)$; the cutaneous muscle fibers edematous without signs of striated structure $(A)$; individual endothelial cells have a swallen appearance with pericytes in the growing capillary network, adjacent to muscle fibers, and cell infiltrations in connective tissue (B); angiogenesis locally concentrated in edematic packless tissue around the two nerves and arterial hyperaemic blood vessels, including the presence of randomly distributed fibroblasts and fibrocytes (C) (H\&E, $40 \mathrm{x}$ )

\section{DISCUSSION}

The term "biomaterial" can be defined as a material used in medicine for the treatment of patients where the material must interface with the host tissue under physiological surrounding, with no immunogenic response, for a significant length of time (Williams, 1987). It is well documented that several calcium phosphate ceramic materials are highly biocompatible (Williams, 1981; Williams, 1981; LeGeros and LeGeros, 1996). Nevertheless, with many orthopedic and dental devices, failure commonly occurs within 5-10 years of implantation (Cook and Dalton, 1992; LeGeros and LeGeros, 1996). An understanding of the interaction between ceramics and the physiological environment of the human body is important in devising effective ceramic implants used in various treatment applications (Coleman et al., 1974; Tang et al., 1996).

Several investigators suggested that calcium phosphate-based ceramics cause slight to no inflammatory response when introduced into the host tissue (Williams, 1986; Donath, 1989; Butler et al., 2001). Varying host inflammatory responses may be attributed to size, shape, topography, site, and duration of the implantation (Williams, 1981; Williams, 1986). According to Williams (1986), the severity of inflammatory response after implantation of the biomaterial, is based upon the number, type and location of inflammatory cells. A minimal tissue reaction at both 2 and 12 weeks is defined as tissue which is well organized, with no more inflammatory reaction at the exposure points. A moderate tissue reaction is defined as one where at 2 weeks there are some inflammatory cells (at the ends 
of the inserted tube and no - to minimal numbers along its midsection). The tissue adjacent to the test substance retains its structure, but does contain some leukocytes, lymphocytes, plasma cells, macrophages and foreign body giant cells. At 12 weeks there is only fibrous tissue along the midsection with some chronic inflammatory cells, lymphocytes, plasma cells, macrophages and giant cells. A severe tissue reaction was defined as one where there is a distinct reaction at the ends of the tube at 2 weeks with the tissue having lost its structure and containing an accumulation of cells, but fibrous uninflamed tissue exists along the midsection. At 12 weeks the end tissue may have regained some structure, but still contains an accumulation of cells. According to Williams, our results indicate that alpha TCP ceramic and other examined calcium phosphate ceramics caused a moderate inflammatory tissue reaction at 2 and 12 weeks after implantation.

However, there are a few contributing factors to these results. It is suspected that the main contributing factor of tissue-implant reaction is the surgical procedure itself, which causes tissue damage to a limited area, and this was to be expected (Williams, 1986; Marion et al., 1980). In this preliminar study, implantation of bioceramics at a tissue level initiates reactions typical for a surgical procedure, i.e. wounds, and aftermath reactions of regeneration, organization and healing of a wound, and, in this case, of foreign material adopting processes by the tissue. High cellularity was expected to be present during the early stages of the experiment. The consequence is substitutional growth, i.e. creation of new cells replacing the lost ones. There were slight variations in tissue-implant reactions between different ceramics, which lead to possible good biocompatibility of newly synthesized aTCP (as it is the case of a virtually nontoxic, non-immunogenic, and almost chemically inert dental ceramic and hydroxyapatite ceramic). Aforementioned data indicates tissue restitution being common for all three analyzed bioceramics.

Implant movement during tissue processing could result in a variable degree of mechanically induced tissue damage (Marion et al., 1980; Williams, 1986). The presence of neutrophils is suspected to be the next contributing factor for the fibrous tissue surrounding calcium phosphate ceramics. Also, broken fibers of cutaneous muscle are present. In that regard, our results are, again, consistent with the literature data.

Yang et al. (1996) examined osteogenesis in extraskeletally implanted porous calcium phosphate ceramics and described its variability among different animal species. Around the ceramic implants into the dorsal muscle of rats there was no newly formed bone tissue as it was the case in other animal species (dogs, pigs). In rats, only dense fibrous connective tissue capsules formed and the pore areas were filled with loose connective tissue.

Analyses of the tissue-implant reaction, twelve weeks after implantation, revealed that a layer of fibro-adipose tissue containing small blood vessels and capillaries. Angiogenesis was well developed in the connective tissue in all analized samples. This is in agreement with data from other research groups (Butler et al., 2001; Benguzzi, 1996). These ceramics have a vast application in many areas. In drug delivery applications, the inflammatory response must be considered, because this is the mechanism by which the implant is interfaced with 
Acta Veterinaria (Beograd), Vol. 58. No. 4, 381-393, 2008.

Stojanović D et al.: A tissue-implant reaction associated with subcutan implantation of alpha-tricalcium phosphate, dental ceramic and hydroxyapatite bioceramics in rats

the host tissue, providing a rich vascular supply (Meachim and Pedley, 1993; Tarr et al., 1997).

In conclusion, this study provides a qualitative analysis of tissue-implant reaction of moderate acute and chronic inflammatory response associated with subcutaneous implantation of alpha tri-calcium phosphate, dental ceramic, and hydroxyapatite bioceramics in rats. Using this animal model we demonstrated that there are significant differences in the tissue-implant reactions based on the estimated time, while there are no differences in the tissue-implant reaction based on the type of ceramic material. Two weeks after implantation hyperemia and cellular infiltration were the most expressive findings, while twelve weeks after implantation extensive angiogenesis and collagen fibers production were a prominent finding for all types of implanted calcium phosphate ceramics. All three calcium phosphate ceramics induced a well developed fibrous tissue in the surrounding area. In order to better understand the physiological response to calcium phosphate devices, further investigation is needed to elucidate a qualitative tissue-implant reaction, such as if the numbers of macrophages, neutrophils, fibroblasts, collagen and blood vessels are highly variable between ceramic ceramic groups.

\section{ACKNOWLEDGEMENTS:}

This work was supported by the Ministry for Science and Environmental Protection of Republic of Serbia, Grant numbers 143055 and 145053. The authors also thank Veterinary technicians Dragiša Nikitović and Dragana Pavlović, from the Institute of Physiology, School of Medicine, for excellent technical assistance.

Address for correspondence:

Kojić Zvezdana

Institute of Medical Physiology

School of Medicine

University of Belgrade

Višegradska 26/II

11000 Belgrade, Serbia

e-mail: zvezdana@yubc.net

\section{REFERENCES}

1. Barile F, 2008, Subchronic and chronic toxicology testing, Chapter 7, In: Principles of Toxycology testing, CRC Press, Taylor \& Francis Group, 89-99.

2. Benguzzi $H, 1996$, Cytological evaluation of capsular tissue surrounding TCPL implant in adult rats, Biomed Sci Instrum, 32, 81-6.

3. Butler K, Benguzzi $H$, Puckett A, 2001, Cytological evaluation of the tissue-implant reaction associated with S/C and I/P implantation of ALCAP and HA bioceramics in vivo, Pathol Res Pract, 197,1, 29-39.

4. Coleman $D L$, King $R N$, Andrade JD, 1974, The foreign body reaction: a chronic inflammatory response, J Biomed Mat Resor, 8, 191-211.

5. Cook SD, Dalton JE, 1992, Biocompatability and biofunctionality of implanted materials, Alpha Omegan, 85, 41-7.

6. Donath K, 1989, Tissue reaction to Ca-phosphate ceramics, In: Hironobu O, Hideki A, Kazuhiko S (Eds) Bioceramics Proceedings of the 1st International Bioceramic Symposium, 1st ed, 96-101, Ishiyaku Euro America, Inc, Tokyo. 
Acta Veterinaria (Beograd), Vol. 58. No. 4, 381-393, 2008.

Stojanović $\mathrm{D}$ et al.: A tissue-implant reaction associated with subcutan implantation of alpha-tricalcium phosphate, dental ceramic and hydroxyapatite bioceramics in rats

7. Fellah BH, Josselin N, Chappard D, 2007, Inflammatory reaction in rat muscle after implantation of biphasic calcium phosphate micro particles, J Mater Sci Mater Med, 18, 2, $287-94$.

8. Jokic B, Jankovic-Castvan J, Veljovic Dj, Bucevac D, Obradovic-Djuricic K, Petrovic R, Janackovic $D j, 2007$, Synthesis and Settings Behaviour of $\alpha$-TCP from Calcium Defficient Hyroxyapatite obtained by Hydrothermal Method, J Optoelectron Adv Mater, 9, 1904-10.

9. LeGeros $R Z$ and LeGeros JP, 1996, Calcium phosphate biomaterials in medical application, Bioceramics, 9, 7-10.

10. Lu B, LuX, Zhang ZI, 2004, Application of enzyme histochemistry in evaluation of in vitro and in vivo biocompatibility of HA/TCP, Sheng Wu Yi Xue Gong Cheng Xue Za Zhi, 21, 4, 631-5.

11. Marion L, Haugen E, Mjor IA, 1980, Methodological assessments of subcutaneous implantation techniques, J Biomed Mater Resour, 14, 343-57.

12. Meachim G, Pedley RB, 1993, The tissue response at implant sites, In: Williams DF (Ed) Fundamental Aspects of Biocompatibility, 1, 1st ed, 108-47, CRC Press, Boca Raton.

13. Tang L, Ugarova T, Plow E, Eaton J,1996, Molecular determinants of acute inflammatory responses to biomaterials, $J$ Clin Investig 97,5, 1329-44.

14. Tarr ER, Lasserre A, Szmulowicz U, Bajpai PK, 1997, A hydroxyapatite system for the continous release of coumadin, an anticoagulant, Biomed Sci Instrument, 33, 143-50.

15. Williams DF, 1987, Definitions in biomaterials, Elsevier, Oxford, 20-9.

16. Williams DF, 1981, Biomaterials and biocompatibility: an introduction, In: Williams DF (Ed), Fundamental Aspects of Biocompatibility, CRC Press, Boca Raton, Florida, 1-7.

17. Williams DF, 1981, Toxicology of ceramics, In: Williams DF (Ed), Fundamental Aspects of Biocompatibility, CRC Press, Boca Raton, Florida, 87-94.

18. Williams DF, 1986, Analyses of soft tissue response to biomaterials, In: Williams DF (Ed), Techniques of Biocompatibility testing, CRC Press, Boca Raton, Florida, 84-115.

19. Yamada M, Shiota M, Yamashita Y, Kasugai S, 2007, Histological and histomorphometrical comparative study of the degradation and osteoconductive characteristics of alpha- and betatricalcium phosphate in block grafts, J Biomed Mater Res B Appl Biomater, 82, 1, 139-48.

20. Yang Z, Yuan H, Tong W, et al., 1996, Osteogenesis in extraskeletally implanted porous calcium phosphate ceramics: variability among different kinds of animals, Biomaterials, 17, 22, 2131-7.

\title{
TKIVO - IMPLANT REAKCIJA POVEZANA SA SUBKUTANOM IMPLANTACIJOM ALFA-TRIKALCIJUM FOSFATA, DENTALNE KERAMIKE I HIDROKSIAPATIT BIOKERAMIKE KOD PACOVA
}

\author{
STOJANOVIĆ D, JANAČKOVIĆ Đ, MARKOVIĆ DANICA, TASIĆ G, ALEKSANDRIĆ B i \\ KOJIĆ ZVEZDANA
}

\section{SADRŽAJ}

Podaci iz literature ukazuju da se kalcijum fosfatna keramika ubraja među najčešće korišćene i biološki najkompatibilnije keramičke materijale koji se danas primenjuju u medicini. U našoj laboratoriji sintetisana je nova vrsta kalcijum fosfatne keramike, alfa-trikalcijum fosfat (aTCP). Cilj ovog rada je bio da se proceni biokompatibilnost ovog, modifikovanog, novosintetisanog aTCP, putem pažljive procene inflamatorne reakcije mekog tkiva koja nastaje kao odgovor na njegovu subkutanu implantaciju i putem upoređivanja ovih rezultata sa rezultatima subku- 
Acta Veterinaria (Beograd), Vol. 58. No. 4, 381-393, 2008.

Stojanović D et al.: A tissue-implant reaction associated with subcutan implantation of alpha-tricalcium phosphate, dental ceramic and hydroxyapatite bioceramics in rats

tane implantacije dentalne keramike (DC) i hidroksiapatita (HAP), koji su ne-toksični, ne-imunogeni i skoro hemijski potpuno inertni. Kod 12 odraslih mužjaka Wistar pacova implantirani su subkutano implanti aTCP, DC i HAP (disk 5x2 mm). Na kraju 2. i 12. nedelje nakon implantacije, životinje su žrtvovane i reakcija tkivoimplant je analizirana histološki. Analiza rutinski obojenih $(5 \mu \mathrm{m}$, hemotoksilin \& eozin) isečaka tkiva kutisa i subkutisa koje se nalazilo oko implantiranog aTCP, DC i HAP, otkrila je sledeće: 1) svi keramički implanti bili su okruženi fibroznom kapsulom; 2) u odnosu na vreme posle implantacije, postojale su značajne razlike u tkivo-implant reakciji, dok u odnosu na vrstu keramičkog materijala, nisu postojale razlike u reakciji tkiva na implant; 3) za sve tri vrste implantirane kalcijum-fosfatne keramike, glavni nalaz u tkivu bio je, dve nedelje nakon implantacije, hiperemija i ćelijska infiltracija, dok nakon 12 nedelja prisutna intenzivna angiogeneza i stvaranje kolagenih vlakana. 